\title{
RAINFALL EROSIVITY AND RAINFALL RETURN PERIOD IN THE EXPERIMENTAL WATERSHED OF ARACRUZ, IN THE COASTAL PLAIN OF ESPIRITO SANTO, BRAZIL ${ }^{(1)}$
}

\author{
Sérgio Gualberto Martins ${ }^{(2)}$, Junior Cesar Avanzi ${ }^{(3)}$, Marx Leandro Naves \\ Silva $^{(3)}$, Nilton Curi ${ }^{(3)}$, Lloyd Darrell Norton ${ }^{(4)}$ \& Sebastião Fonseca $^{(5)}$
}

\begin{abstract}
SUMMARY
Knowledge on the factors influencing water erosion is fundamental for the choice of the best land use practices. Rainfall, expressed by rainfall erosivity, is one of the most important factors of water erosion. The objective of this study was to determine rainfall erosivity and the return period of rainfall in the Coastal Plains region, near Aracruz, a town in the state of Espírito Santo, Brazil, based on available data. Rainfall erosivity was calculated based on historic rainfall data, collected from January 1998 to July 2004 at 5 min intervals, by automatic weather stations of the Aracruz Cellulose S.A company. A linear regression with individual rainfall and erosivity data was fit to obtain an equation that allowed data extrapolation to calculate individual erosivity for a 30 -year period. Based on this data the annual average rainfall erosivity in Aracruz was 8,536 $\mathrm{MJ} \mathrm{mm} \mathrm{ha}{ }^{-1} \mathrm{~h}^{-1} \mathrm{yr}^{-1}$. Of the total annual rainfall erosivity $85 \%$ was observed in the most critical period October to March. Annual erosive rains accounted for $38 \%$ of the events causing erosion, although the runoff volume represented $88 \%$ of the total. The annual average rainfall erosivity return period was estimated to be 3.4 years.
\end{abstract}

Index terms: kinetic energy, R-factor, USLE, recurrence interval, probability of occurrence.

\footnotetext{
(1) Part of the Ph.D. thesis of the first author. Received for publication in January 2009 and approved in March 2010.

(2) Árvore Consultoria Soluções Ambientais, Rua Desembargador Dário Lins, 14, Apto 101, Centro, CEP 37200-000 Lavras (MG) Brazil. E-mail: sergio@arvoreconsultoria.com.br

(3) Department of Soil Science, Federal University of Lavras, C.P. 3037, CEP 37200-000 Lavras, (MG) Brazil. E-mail: javanzi@gmail.com; marx@dcs.ufla.br; niltcuri@dcs.ufla.br

(4) USDA-ARS National Soil Erosion Research Laboratory, 275 South Russell Street, Purdue University, 47907-2077 West Lafayette (IN) USA. E-mail: norton@purdue.edu

(5) Fibria Celulose S.A. Rodovia Aracruz, Barra do Riacho, km 25, C.P. 331011, CEP 29197-000 Aracruz (ES) Brazil. E-mail: sf@fibria.com.br
} 


\title{
RESUMO: EROSIVIDADE DA CHUVA E TEMPO DE RETORNO NA BACIA EXPERIMENTAL DA ARACRUZ, REGIÃO DOS TABULEIROS COSTEIROS BRASILEIROS
}

\begin{abstract}
O conhecimento dos fatores que influenciam a erosão hídrica é de fundamental importância no planejamento do uso do solo. Dos fatores que alteram a erosão, a precipitação pluvial, expressa pela erosividade da chuva, é um dos mais importantes. Assim, o objetivo deste estudo foi determinar a erosividade e o tempo de retorno para a região dos Tabuleiros Costeiros, no municipio de Aracruz, ES. Para o cálculo da erosividade, foram utilizados dados pluviométricos de janeiro de 1998 a julho de 2004, obtidos em estações climatológicas automatizadas, localizadas em área experimental da Aracruz Celulose AS, que, para este estudo, geraram dados de 5 em $5 \mathrm{~min}$. A análise de regressão linear entre precipitação pluvial e erosidade para esse período permitiu obter uma equação, a qual foi usada para estimar os valores de erosidade para uma série histórica de 30 anos. A erosividade média anual foi de

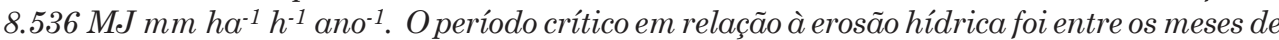
outubro e março. As chuvas erosivas representaram $38 \%$, mas, em volume, isso representou $88 \%$ do total precipitado por ano. O período de retorno para o valor médio de erosividade foi estimado em 3,4 anos.
\end{abstract}

Termos de indexação: energia cinética, fator $R$, USLE, intervalo de recorrência, probabilidade de ocorrência.

\section{INTRODUCTION}

Rainfall erosivity is the most important factor involved in soil erosion caused by water. Rainfall erosivity is represented by the $\mathrm{R}$ factor in the Universal Soil Loss Equation (USLE) and it is expressed by $\mathrm{EI}_{30}$ parameter. This represents the product of the raindrop impact kinetic energy $(\mathrm{E})$ and maximum 30 min rainfall intensity $\left(\mathrm{I}_{30}\right)$ (Wischmeier $\&$ Smith, 1978). The relationship of rainfall intensity and raindrop size distribution is the basis for the equations originally proposed by Wischmeier \& Smith (1958). This ratio indicates the erosive effect of raindrop impact and runoff (Lal, 1988).

The $\mathrm{EI}_{30}$ parameter has been widely used by several Brazilian researchers to express rainfall erosivity. Results have shown good correlations with soil losses. Natural rainfall has significant variability according to the large local variations in physical characteristics.

In several regions in Brazil values of rainfall erosivity were found within the range of 5,000 to 12,000 MJ mm ha-1 $\mathrm{h}^{-1} \mathrm{yr}^{-1}$ (Cogo, 1988). The following authors have reported rainfall erosivity for a number of regions in Brazil: Dedecek (1978), Val et al. (1986), Carvalho et al. (1989), Morais et al. (1991), Campos Filho et al. (1992), Lopes \& Brito (1993), Silva et al. (1997), Marques et al. (1998), Roque et al. (2001), Bertol et al. (2002), Colodro et al. (2002), Silva \& Dias (2003), Aquino (2005), Bazzano et al. (2007), Mello et al. (2007), Hickmann et al. (2008) and Silva et al. (2009). Rainfall events are random and hard to predict in advance, and statistics have been used as a means of analyzing rainfall data (Tucci, 2007). In this context, knowledge about rainfall erosivity is very important, for example, to avoid high soil losses and damage in agricultural production systems.

The rainfall event with maximum erosivity can be estimated by analyzing the event frequency of return periods. The return period or recurrence interval is defined as a statistical measure representing the average recurrence interval over an extended period of time, measured in years, or the expected frequency of a given event to happen at a particular site (Unger, 2006; Tucci, 2007). Calculations of return periods are used to design various erosion control and water conservation structures and practices (e.g., terraces, waterways, and ponds). Consequently, rainfall frequency and risk should be taken into consideration in order to design the most adequate water control practices (Bazzano et al., 2007).

In the land management for agricultural purposes the potential of rainfall erosion should be taken into account. The purpose of this study was to evaluate rainfall erosivity under natural rain and the rainfall erosivity return periods in the Aracruz Experimental Watershed, in the Coastal Plain of Espirito Santo state, Brazil.

\section{MATERIALS AND METHODS}

\section{Study area}

Rainfall data were collected in an experimental watershed in the area of the company Aracruz Cellulose S.A., Aracruz, Espirito Santo state, Brazil $\left(19^{\circ} 35^{\prime}\right.$ to $20^{\circ} 15^{\prime} \mathrm{S} ; 40^{\circ} 00^{\prime}$ to $40^{\circ} 20^{\prime} \mathrm{W}$; $40 \mathrm{~m}$ 
above sea level. According to Köppen's classification, the regional climate is Aw (tropical with wet summer and dry winter) and the annual precipitation $1,400 \mathrm{~mm}$; in one or two months precipitation is $<60 \mathrm{~mm}$. Spring and summer account for $65-75 \%$ of the total precipitation (Embrapa, 2000). The watershed has a drainage area of 286 ha, 190 ha of which are eucalyptus plantations, 86 ha are native forest (Atlantic Forest) and the remaining 10 ha are forest roads.

\section{Rainfall data analyses}

Rainfall data were recorded every $5 \mathrm{~min}$ from January 1998 to July 2004. Only rainfall events $>10 \mathrm{~mm}$, with maximum intensity $>24 \mathrm{~mm} \mathrm{~h}^{-1}$ within $15 \mathrm{~min}$, or kinetic energy $>3.6 \mathrm{MJ}$ were used in this study to calculate the rainfall erosivity parameter. Long rainfall events were distinguished from one to another if there was a $6 \mathrm{~h}$ period between them with $<1 \mathrm{~mm}$ of precipitation. Kinetic energy was computed for all rain events using the equation of Wischmeier \& Smith (1958):

$$
\mathrm{E}=0.199+0.0873 \log \mathrm{I}
$$

where: $\mathrm{E}$ is kinetic energy ( $\mathrm{MJ} \mathrm{ha}^{-1} \mathrm{~mm}^{-1}$ ), and $\mathrm{I}$ is rainfall intensity $\left(\mathrm{mm} \mathrm{h}^{-1}\right)$.

The $\mathrm{EI}_{30}$ parameter for a specific event was calculated as the product of total kinetic energy (E) and the maximum 30 min intensity $\left(\mathrm{I}_{30}\right)$, according to Wischmeier \& Smith (1958). Monthly values were determined as the sum of the individual events determined $\mathrm{EI}_{30}$ parameter $\left(\mathrm{MJ} \mathrm{mm} \mathrm{ha}^{-1} \mathrm{~h}^{-1}\right)$, and annual values were determined in the same manner.

A linear regression between individual rainfall and rainfall erosivity (measured data) was fit in order to obtain an equation that allows estimating individual rainfall erosivity for a historical period of 30 years (1968-1997). To obtain annual rainfall erosivity values for this period, historical rainfall erosivity was based on measured data (1998-2004).

\section{Return period determination}

The theoretical return period is the inverse of the probability that the event will be exceeded in any given year. The return period and the probability for the annual rainfall erosivity data (1968 - 2004) were obtained using the following equation (Schwab et al., 1981).

$$
\begin{gathered}
\mathrm{P}=100 / \mathrm{T} \\
\mathrm{T}=(\mathrm{N}+1) / \mathrm{m}
\end{gathered}
$$

where: $\mathrm{P}$ is the probability of occurrence of rainfall erosivity parameter, in \%; $\mathrm{T}$ is the return period, in years, which the rainfall erosivity parameter will be equaled or exceeded; $\mathrm{N}$ is the number of years on record; and $\mathrm{m}$ is the rank of the event being considered.

\section{RESULTS AND DISCUSSION}

\section{Rainfall amount and distribution}

The total number of 1,048 rainfall events was studied, of which only $38 \%$ were erosive (Figure 1a). The majority of erosive events occurred in the period from October to March (Figure 1b); hence, special attention must be paid to soil protection during this period. The average rainfall in this period was $1,189 \mathrm{~mm}$ and erosive rainfalls accounted for $1,041 \mathrm{~mm}$ (Figure 1b). This shows that most of the rain is concentrated in few rainfall events (38\%). Other scientists (Eltz, 1977; Bertol, 1993; Schick, 1999; Beutler, 2000; Hickmann et al., 2008) found the same trend in other regions of Brazil. These results also agree with Hudson (1995), who showed that about $40 \%$ of the total rainfall events in the tropics are erosive.

\section{Rainfall erosivity}

The average monthly values ranged from 88 to $2,416 \mathrm{MJ} \mathrm{mm} \mathrm{ha}^{-1} \mathrm{~h}^{-1}$. The monthly erosive value was lowest in May and highest in March (Figure 2a). In December the rainfall erosivity value in Aracruz
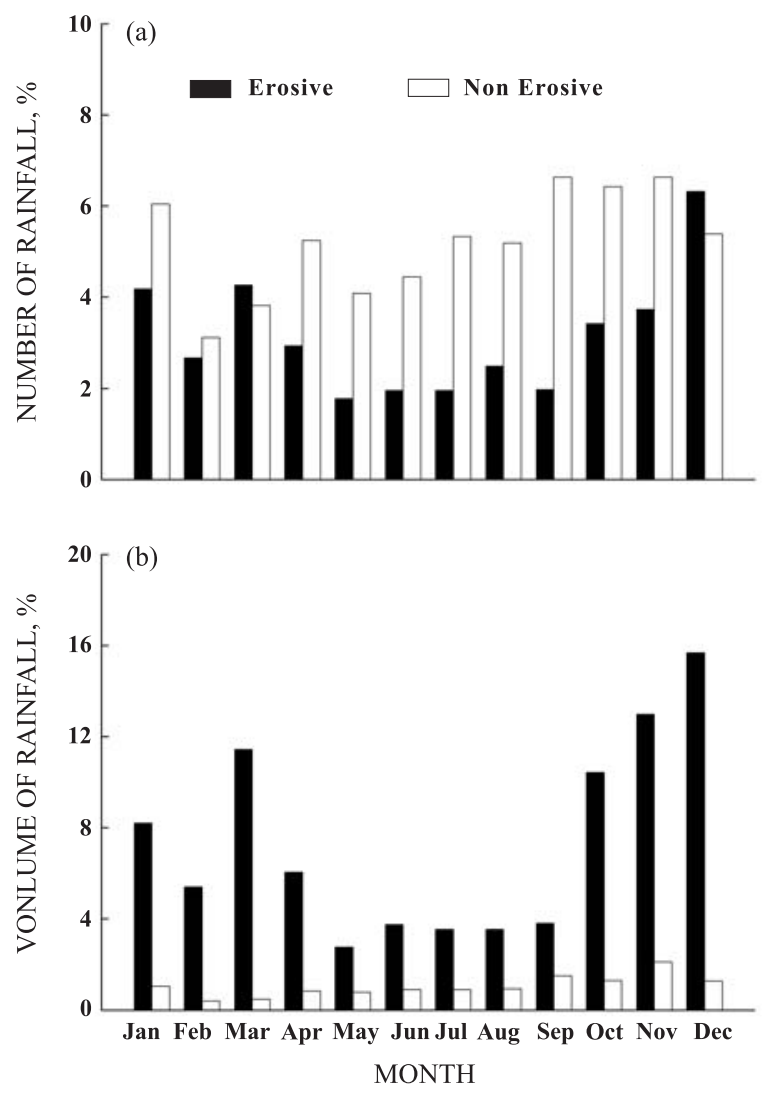

Figure 1. Number of rainfalls (a), and volume of erosive and non-erosive rainfall events; rainfall events $>10 \mathrm{~mm}$, with maximum intensity $>24 \mathrm{~mm} \mathrm{~h}^{-1}$ within $15 \mathrm{~min}$, or kinetic energy $>3.6 \mathrm{MJ}$ were considered erosive (b). 
was greatest. However, there was a large rainfall event $(230 \mathrm{~mm})$ in March 2004 with a rainfall erosivity value of $9,552 \mathrm{MJ} \mathrm{mm} \mathrm{ha}^{-1} \mathrm{~h}^{-1}$. Thus, the rainfall erosivity value of this month was $12,540 \mathrm{MJ} \mathrm{mm} \mathrm{ha}^{-1}$ $\mathrm{h}^{-1}$, exceeding the monthly average. The rainfall erosivity of this extreme event was much greater than the annual average before 2004 (6,499 MJ mm ha-1 $\mathrm{h}^{-1}$ $\left.\mathrm{yr}^{-1}\right)$ and was not typical of the region.

On average, the period from October to March accounted for $85 \%$ of total rainfall erosivity. This can be observed as a steep increase in figure $2 \mathrm{~b}$. This percentage was also found by Bazzano et al. (2007), in Quaraí, RS. These facts show that the occurrence of highly erosive rainfall is concentrated and causes more soil erosion during only that portion of the year. During the fall and winter seasons rainfall events decrease and so do the rainfall erosivity values.

Rufino (1986) considered rainfall erosivity values $>500 \mathrm{MJ} \mathrm{mm} \mathrm{ha}^{-1} \mathrm{~h}^{-1}$ month $^{-1}$ critical. In this research, the rainfall erosivity values exceeded this limit in several months. Therefore, the best management practice should be established in the study region to prevent erosion prior to this time. A best management practice should be able to prevent soil erosion during these extreme rainfall events. In addition, knowing the times of the year when erosion
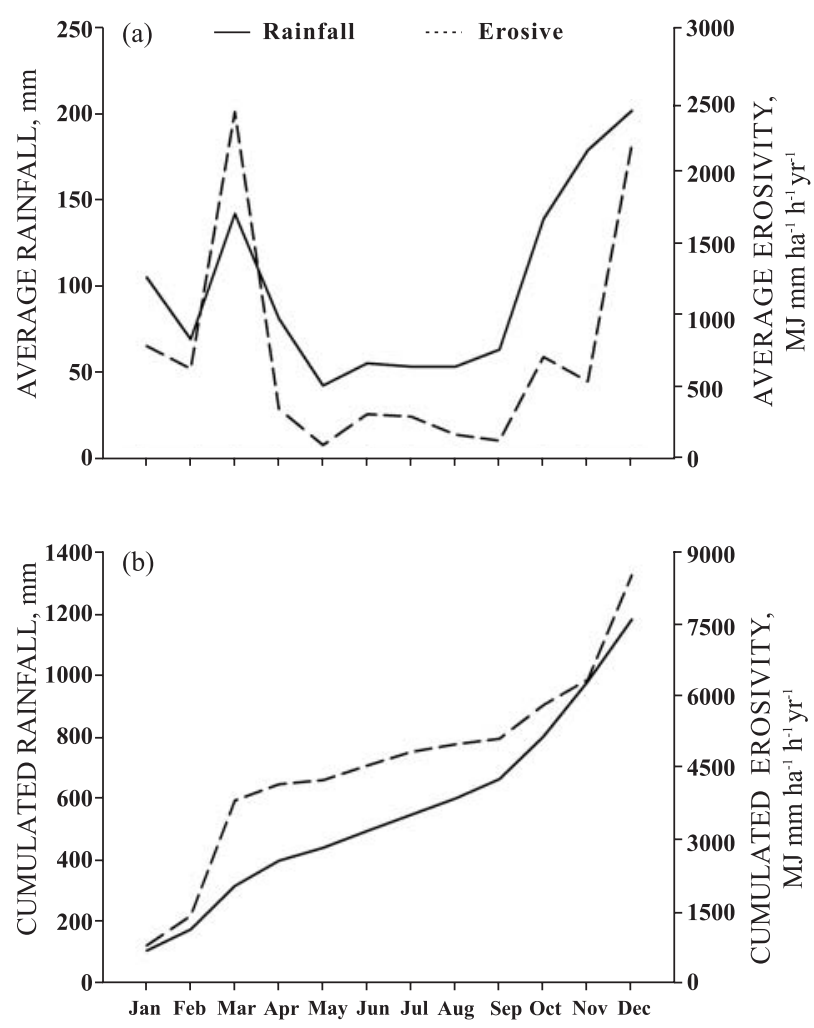

MONTH

Figure 2. Average rainfall and rainfall erosivity from 1998 to 2004 (a). Accumulated average of rainfall and rainfall erosivity (b). risks are more immediate is very helpful for planning conservation activities and land preparation.

Annual rainfall values ranged from 787 to $1,341 \mathrm{~mm}$, annual rainfall erosivity values were between 4,536 and 17,056 MJ mm ha-1 $\mathrm{h}^{-1} \mathrm{yr}^{-1}$ (Table 1). The greatest rainfall erosivity value corresponds to the period between January and May 2004. The lack of information does not allow the determination of a total rainfall erosivity value for 2004 , but the conclusion can be drawn that it would be much greater than in other years since rainfall erosivity values were always higher in December.

Due to the gap in the 2004 values, the total annual value could not be calculated for such year. Then, the monthly average values were summed to obtain the average rainfall erosivity, being equal to 8,536 MJ mm ha-1 $\mathrm{h}^{-1} \mathrm{yr}^{-1}$ (Table 1). This value is quite different from that presented in the rainfall erosivity map of Brazil by Silva (2004), where the rainfall erosivity values of Espírito Santo state vary from 4,000 to 6,000 MJ mm ha-1 $\mathrm{h}^{-1} \mathrm{yr}^{-1}$. The reason for this discrepancy may that the author used only eight equations to estimate and construct the Brazilian rainfall erosivity map.

The R-factor found in this research (8,536 MJ mm $\left.\mathrm{ha}^{-1} \mathrm{~h}^{-1} \mathrm{yr}^{-1}\right)$ is close to that found by Dedecek (1978) for Brasilia, DF (8,319 MJ mm ha-1 $\left.\mathrm{h}^{-1} \mathrm{yr}^{-1}\right)$; Morais et al. (1991) for Barraquinho, MT (8,493 MJ mm ha-1 $\left.\mathrm{h}^{-1} \mathrm{yr}^{-1}\right)$; Silva et al. (1997) for Goiania, GO (8,353 MJ mm ha-1 $\left.\mathrm{h}^{-1} \mathrm{yr}^{-1}\right)$; and Hickmann et al. (2008) for Uruguaiana, RS (8,875 $\left.\mathrm{MJ}^{\mathrm{mm}} \mathrm{ha}^{-1} \mathrm{~h}^{-1} \mathrm{yr}^{-1}\right)$. According to Foster et al. (1981), the rainfall erosivity potential is high in all of theses cases.

\section{Return period}

Based on the daily rainfall erosivity and rainfall a linear equation was calculated $(\hat{y}=7.9075 x-40.578$; $\mathrm{R}^{2}=0.61$ ), where: $\mathrm{y}$ represents the rainfall erosivity

Table 1. Rainfall erosivity parameter and rainfall precipitation in Aracruz, ES, Brazil

\begin{tabular}{lcc}
\hline Year & Rainfall erosivity & Rainfall \\
\hline & MJ mm ha ${ }^{-1} \mathrm{~h}^{-1} \mathrm{yr}^{-1}$ & $\mathrm{~mm}$ \\
1998 & 8,082 & 1,174 \\
1999 & 6,636 & 1,076 \\
2000 & 4,635 & 1,132 \\
2001 & 8,817 & 1,341 \\
2002 & 6,291 & 901 \\
2003 & 4,535 & 787 \\
$2004^{(1)}$ & 17,056 & 1,238 \\
Average $^{(2)}$ & 8,536 & 1,184
\end{tabular}

1) Partial value from events from January to July. ${ }^{(2)}$ Average obtains from monthly average. 
values, and $\mathrm{x}$ the rainfall. This equation was used to estimate daily rainfall erosivity from 1968 to 1997. Rainfall erosivity data estimated according Wischmeier \& Smith (1978) were used for the subsequent period.

The return period and probability of occurrence for the annual rainfall erosivity events in Aracruz, ES, are shown in table 2 . The estimated return period of the highest annual rainfall erosivity value $\left(17,056 \mathrm{MJ} \mathrm{mm} \mathrm{ha}^{-1} \mathrm{~h}^{-1} \mathrm{yr}^{-1}\right)$ was 38 years, with a probability of occurrence of $2.63 \%$. The least annual rainfall erosivity value for the studied period was $4,171 \mathrm{MJ} \mathrm{mm} \mathrm{ha}^{-1} \mathrm{~h}^{-1} \mathrm{yr}^{-1}$, and the estimated return period was 1 year, with a probability of occurrence of $97.37 \%$. Thus, the maximum and minimum rainfall erosivity values are expected every 38 and 1 years, respectively.

Table 2. Probability of occurrence and return period for the annual rainfall erosivity value in the watershed of Aracruz (ES), between 1968 and 2004

\begin{tabular}{|c|c|c|c|c|}
\hline Year & $\begin{array}{l}\text { Rainfall } \\
\text { erosivity } \\
\quad\left(\mathrm{EI}_{30}\right)\end{array}$ & $\begin{array}{c}\text { Ranking } \\
\text { (m) }\end{array}$ & $\begin{array}{c}\text { Probability } \\
\text { (P) }\end{array}$ & $\begin{array}{c}\text { Return } \\
\text { period }(\mathrm{T})\end{array}$ \\
\hline 2004 & 17,056 & 1 & 2.63 & 38.0 \\
\hline 1980 & 11,858 & 2 & 5.26 & 19.0 \\
\hline 1992 & 10,341 & 3 & 7.89 & 12.7 \\
\hline 1973 & 9,886 & 4 & 10.53 & 9.5 \\
\hline 1984 & 9,277 & 5 & 13.16 & 7.6 \\
\hline 1983 & 9,227 & 6 & 15.79 & 6.3 \\
\hline 1975 & 8,990 & 7 & 18.42 & 5.4 \\
\hline 1978 & 8,953 & 8 & 21.05 & 4.8 \\
\hline 2001 & 8,817 & 9 & 23.68 & 4.2 \\
\hline 1995 & 8,805 & 10 & 26.32 & 3.8 \\
\hline 1979 & 8,745 & 11 & 28.95 & 3.5 \\
\hline 1998 & 8,081 & 12 & 31.58 & 3.2 \\
\hline 1974 & 8,045 & 13 & 34.21 & 2.9 \\
\hline 1970 & 8,034 & 14 & 36.84 & 2.7 \\
\hline 1985 & 8,027 & 15 & 39.47 & 2.5 \\
\hline 1991 & 7,877 & 16 & 42.11 & 2.4 \\
\hline 1989 & 7,502 & 17 & 44.74 & 2.2 \\
\hline 1976 & 7,501 & 18 & 47.37 & 2.1 \\
\hline 1996 & 7,179 & 19 & 50.00 & 2.0 \\
\hline 1999 & 6,636 & 20 & 52.63 & 1.9 \\
\hline 1997 & 6,428 & 21 & 55.26 & 1.8 \\
\hline 1981 & 6,380 & 22 & 57.89 & 1.7 \\
\hline 1982 & 6,364 & 23 & 60.53 & 1.7 \\
\hline 2002 & 6,291 & 24 & 63.16 & 1.6 \\
\hline 1969 & 6,274 & 25 & 65.79 & 1.5 \\
\hline 1971 & 6,044 & 26 & 68.42 & 1.5 \\
\hline 1968 & 5,806 & 27 & 71.05 & 1.4 \\
\hline 1972 & 5,548 & 28 & 73.68 & 1.4 \\
\hline 1988 & 5,417 & 29 & 76.32 & 1.3 \\
\hline 1993 & 5,338 & 30 & 78.95 & 1.3 \\
\hline 1977 & 5,282 & 31 & 81.58 & 1.2 \\
\hline 1987 & 5,248 & 32 & 84.21 & 1.2 \\
\hline 1990 & 5,124 & 33 & 86.84 & 1.1 \\
\hline 1994 & 4,674 & 34 & 89.47 & 1.1 \\
\hline 2000 & 4,634 & 35 & 92.11 & 1.1 \\
\hline 2003 & 4,536 & 36 & 94.74 & 1.1 \\
\hline 1986 & 4,171 & 37 & 97.37 & 1.0 \\
\hline
\end{tabular}

The recurrence interval of the observed annual average rainfall erosivity (estimated at 8,536 $\mathrm{MJ} \mathrm{mm}$ $\mathrm{ha}^{-1} \mathrm{~h}^{-1} \mathrm{yr}^{-1}$ ) (Table 1) was 3.4 years, with a probability of occurrence of $29.78 \%$. Colodro et al. (2002) estimated a return period for the average rainfall erosivity parameter of 2.3 years, for Teodoro Sampaio, SP, whereas the estimated return period for Uruguaiana, RS, was two years (Hickmann et al., 2008).

\section{CONCLUSIONS}

1. The annual rainfall erosivity in Aracruz, ES ranged from 4,536 to $17,056 \mathrm{MJ} \mathrm{mm} \mathrm{ha}^{-1} \mathrm{~h}^{-1} \mathrm{yr}^{-1}$ (mean of 8,536 MJ mm ha-1 $\mathrm{h}^{-1} \mathrm{yr}^{-1}$ ). The months in the period from October and March were the most critical ( $85 \%$ of annual rainfall erosivity) and the values highest in December.

2. In Aracruz, ES, $38 \%$ of the rainfall events were classified as erosive, which accounts for $88 \%$ of the total rainfall volume per year.

3. The return period for the annual average rainfall erosivity $\left(8,536 \mathrm{MJ} \mathrm{mm} \mathrm{ha}^{-1} \mathrm{~h}^{-1} \mathrm{yr}^{-1}\right)$ was estimated to be 3.4 years with a probability of occurrence of $29.78 \%$.

\section{LITERATURE CITED}

AQUINO, R.F. Padrões de chuva e variabilidade da erosividade para o Sul de Minas Gerais. Lavras, Federal Universidade de Lavras, 2005. 95p. (Tese de Mestrado)

BAZZANO, M.G.P.; ELTZ, F.L.F. \& CASSOL, E.A. Erosividade, coeficiente de chuva, padrões e período de retorno das chuvas de Quaraí, RS. R. Bras. Ci. Solo, 31:1205-1217, 2007.

BERTOL, I. Índice de erosividade $\left(\mathrm{EI}_{30}\right)$ para Lages $(\mathrm{SC})$ - 1a aproximação. Pesq. Agropec. Bras., 28:1205-1213, 1993.

BERTOL, I.; SCHICK, J.; BATISTELA, O.; LEITE, D.; VISENTIN, D. \& COGO, N.P. Erosividade das chuvas e sua distribuição entre 1989 e 1998 no município de Lages (SC). R. Bras. Ci. Solo, 26:455-464, 2002.

BEUTLER, J.F. Erosão hídrica num Latossolo Vermelho alumínoférrico submetido a diferentes sistemas de preparo e cultivo do solo. Florianópolis, Universidade Federal de Santa Catarina, 2000. 105p. (Tese de Mestrado)

CAMPOS FILHO, R.; SILVA, I.F.; ANDRADE, A.P. \& LEPRUN, J.C. Erosividade da chuva e erodibilidade do solo do Agreste de Pernambuco. Pesq. Agropec. Bras., 27:13631370, 1992.

CARVALHO, M.P.; LOMBARDI NETO, F.; VASQUES FILHO, J. \& CATANEO, A. Erosividade da chuva de Mococa (SP) analisada pelo índice $\mathrm{EI}_{30}$. R. Bras. Ci. Solo, 13:243-249, 1989. 
COGO, N.P. Conceitos e princípios científicos envolvidos no manejo de solo para fins de controle da erosão hídrica. In: CONGRESSO BRASILEIRO DE CIÊNCIA DO SOLO, 21., Campinas, 1988. Anais... Campinas, Sociedade Brasileira de Ciência do Solo, 1988. p.251-262.

COLODRO, G.; CARVALHO, M.P.; ROQUE, C.G. \& PRADO, R.M. Erosividade da chuva: Distribuição e correlação com a precipitação pluviométrica de Teodoro Sampaio (SP). R. Bras. Ci. Solo, 26:809-818, 2002

DEDECEK, R.A. Capacidade erosiva das chuvas de Brasília DF. In: ENCONTRO NACIONAL DE PESQUISA SOBRE CONSERVAÇÃO DO SOLO, 2., Passo Fundo, 1978. Anais... Passo Fundo, Embrapa-SNLCS, 1978. p.157-161.

ELTZ, F.L.F. Perdas por erosão sob precipitação natural em diferentes manejos de solo e coberturas vegetais. Porto Alegre, Universidade Federal do Rio Grande do Sul, 1977. 97p. (Tese de Mestrado)

EMPRESA BRASILEIRA DE PESQUISA AGROPECUÁRIA EMBRAPA. Centro Nacional de Pesquisa de Solos. Levantamentos generalizado e semidetalhado de solos da Aracruz Celulose S. A. no Estado do Espírito Santo e no estremo sul do Estado da Bahia e sua aplicação aos plantios de eucalipto. Rio de Janeiro, 2000. Parte 3.

FOSTER, G.R.; McCOOL, D.K.; RENARD, K.G. \& MOLDENHAUER, W.C. Conversion of the universal loss equation to SI metric units. J. Soil Water Conserv., 36:355359,1981 .

HICKMANN C.; ELTZ, F.L.F.; CASSOL, E.A. \& COGO, C.M. Erosividade das chuvas em Uruguaiana, RS, determinada pelo índice $\mathrm{EI}_{30}$, com base no período de 1963 a 1991 . R. Bras. Ci. Solo, 32:825-831, 2008.

HUDSON, N.W. Soil conservation. 3.ed. Ames, University Press, 1995. 391p.

LAL, R. Erodibility and erosivity. In: LAL, R., ed. Soil erosion research methods. Ankeny, SWCS, 1988. p.141-160.

LOPES, P.R.C. \& BRITO, L.T.I. Erosividade da chuva no Médio São Francisco. R. Bras. Ci. Solo, 17:129-133, 1993.

MARQUES, J.J.G.S.M.; ALVARENGA, R.C. \& CURI, N. Erosividade das chuvas na região de Sete Lagoas, MG. Pesq. Agropec. Bras., 33:761-768, 1998.

MELLO C.R.; SÁ, M.A.C.; CURI, N.; MELLO, J.M.; VIOLA, M.R. \& SILVA, A.M. Erosividade mensal e anual da chuva no Estado de Minas Gerais. Pesq. Agropec. Bras., 42:537$545,2007$.
MORAIS, L.F.B.; SILVA, V.; NASCHENVEN, T.M.C.; HARDOIN, P.C.; ALMEIDA, J.E.L.; WEBER, O.L.S.; BOEL, E. \& DURIGON, V. Índice $\mathrm{EI}_{30}$ e sua relação com o coeficiente de chuva do sudoeste do Mato Grosso. R. Bras. Ci. Solo, 15:339-344, 1991.

ROQUE, C.G.; CARVALHO, M.P. \& PRADO, R.M. Fator Erosividade da chuva de Piraju (SP): Distribuição, probabilidade de ocorrência, Período de retorno e correlação com o coeficiente de chuva. R. Bras. Ci. Solo, 25:147-156, 2001.

RUFINO, R.L. Avaliação do potencial erosivo da chuva para o Estado do Paraná: Segunda aproximação. R. Bras. Ci. Solo, 10:279-281, 1986.

SCHICK, J. Erosão hídrica em Cambissolo Húmico álico submetido a diferentes sistemas de preparo e cultivo do solo. Florianópolis, Universidade Federal de Santa Catarina, 1999. 114p. (Tese de Mestrado)

SCHWAB G.O.; FREVERT, R.K.; EDMINSTER, T.W. \& BARNER, K.K. Soil and water conservation engineering. 3.ed. New York, John Wiley \& Sons, 1981. 525p.

SILVA, A.M. Rainfall erosivity map for Brazil. Catena, 57:251259,2004

SILVA, A.M.; SILVA, M.L.N.; CURI, N.; AVANZI, J.C. \& FERREIRA, M.M. Erosividade da chuva e erodibilidade de Cambissolo e Latossolo na região de Lavras, Sul de Minas Gerais. R. Bras. Ci. Solo, 33:1811-1820, 2009.

SILVA, J.R.C. \& DIAS, S. A erosividade das chuvas em Fortaleza (CE). II - Correlação com o coeficiente de chuva e atualização do fator R no período de 1962 a 2000. R. Bras. Ci. Solo, 27:347-354, 2003.

SILVA, M.L.N.; FREITAS, P.L.; BLANCANEAUX, P. \& CURI, N. Índices de erosividade das chuvas da Região de Goiânia (GO). Pesq. Agropec. Bras., 32:977-985, 1997.

TUCCI, C.E.M. Hidrologia: Ciência e aplicação. Porto Alegre, ABRH-EDUSP, 2007. 944p.

UNGER, P.W. Soil and water conservation handbook: Policies, practices, conditions and terms. New York, The Haworth Press, 2006. 248p.

VAL, L.A.; BAHIA, V.G.; FREIRE, J.C. \& DIAS JÚNIOR, M.S. Erosividade das chuvas em Lavras - MG. Ci. Prática, 10:199-209, 1986.

WISCHMEIER, W.H. \& SMITH, D.D. Predicting rainfall erosion losses: A guide to conservation planning. Washington, USDA, 1978. 58p. (Agriculture HandBook, 537)

WISCHMEIER, W.H. \& SMITH, D.D. Rainfall energy and its relationships to soil loss. Trans. Am. Geophys. Union, 39:285-291, 1958. 